\title{
Research on Problems and Strategies in General Education of Arts in Colleges and Universities
}

\author{
Xiuli Yang1, a \\ ${ }^{1}$ School of arts, Shandong University of Finance \& Economics, Jinan, China \\ a appleyaya@163.com
}

Keywords: General Education in Colleges and Universities, Arts, Problems and Strategies

\begin{abstract}
The general arts curriculum in colleges and universities is the core of humanistic general education, which undertakes the important task of opening people's perception, imagination and creativity and makes people's inner feelings develop harmoniously. Nowadays, although the general education of arts has been paid more attention to by all the colleges and universities, there are still many problems under the restriction of teachers' experience and development conditions. Therefore, the urgent task for future development is to establish ability index and exchange mechanism in the field of general education of arts, perfect the teaching evaluation system, deepen the teaching concept and make innovation in the teaching mode for general education of arts, and ultimately achieve the goal of improvement in teaching quality and effect for general education.
\end{abstract}

\section{Introduction}

Art is the vestige of human culture and history, which contains rich humanistic and spiritual values. It has an indispensable position in general education. As early as the pre-Qin period, Confucius put forward the ideology of "start from Poetry", "regulate by propriety and form by music", which laid the theoretical foundation of "harmony of manners and rites" for ancient China education.

Platon in ancient Greece also regarded aesthetic education as a special way or supplementary means of moral education, and thought that aesthetic education should belong to moral education. Schiller, one of the representatives of German classical aesthetics, in his book of On the Aesthetic Education of Man, compared the society of ancient Greece with the modern civilization. In his opinion of ancient Greek society, human nature was full of harmony, people were with perfect personality, and individual and society were also very harmonious. It is the most perfect form of society that the whole society, from material and spiritual, emotional and rational, realistic and ideal and so on, achieves a natural and harmonious unified structure. With the development of social economy, social structure and social relations between the society and individuals show a multi-level and diversified phenomenon. Only through aesthetic education can it make people realizing spiritual liberation, obtain the perfect, harmonious and all-round developing humanity. Cai, Yuanpei, a modern educationist in China, also advocated that "aesthetic education displaces religion", and regarded it as the trend of human culture development. He said, "Aesthetic educators are those who apply the theory of aesthetics to education aiming at cultivating feelings." ${ }^{1}$

At present, the purpose of setting up curriculum of general education of arts in colleges and

1 Cai, Yuanpei, The Selected Works of Aesthetics, page 174, Peking University Press, 1983 edition 
universities is the same as to cultivate the students' humanistic literacy, expression and communication skills, ability of lifelong learning, providing with complete knowledge and methods in order to cultivate and improve personality of students in colleges and universities. It is the core of aesthetic education, which undertakes the important task of opening people's perception, imagination and creativity and make people's inner feelings develop harmoniously. From academic scope aspect, the general art curriculum of college and university is a general curriculum in the humanities field. It has a deep influence on university students' humanistic accomplishment and aesthetic taste, which, in other words, may be described as the core of humanistic education, with the target focusing on cultivating the culture and aesthetic appreciation experience, so as to enhance the students' cognition of human arts and cultural heritage.

\section{Nowadays Main Problems Existing in the Practice of General Art Curriculums in Colleges and Universities}

The scope and range of general art curriculums in the universities are very extensive. Throughout the general art curriculums in universities both at home and abroad, the curriculum categories and contents include visual arts, music, drama, performing and interdisciplinary curriculums. However, as the concept of general education of arts in domestic colleges and universities lags behind, there are problems existing in cognitive differences, lack of teachers, outdated equipment and unreasonable curriculum design, resulting in uneven quality in the actual effect of the general education of arts. Some teachers, in order to attract students to take the curriculum, tend to make the curriculum more entertaining, thus losing the original meaning of the curriculum. At present, although the general education of arts has received widespread attention from colleges and universities, there are still many problems due to lack of experience and short development period. The author summarizes the problems as following:

\subsection{Lack of Understanding in the Aesthetic Theory of Shaping Students in Improving Their Personality}

As a part of higher education, general education has been more and more highlighted in the educational concept of teaching and educating people. As an integral part of humanistic education, the importance of art education is self-evident in aesthetic education. Art can affect a person's character, and illuminate the road ahead; art can fully mobilize people's imagination and abstract thinking, and is the necessary quality in shaping extraordinary achievements while no any other discipline category can be compared of. Only by reforming the educational concept of general education of arts and recognizing its position and function in colleges and universities, can it arouse people's cognition and deep thinking. The general art curriculum in domestic colleges and universities has a late start, which is in a subordinate position in quality education; administrative departments for education and all the colleges and universities also fail to pay enough attention to it, often taking common research for university students instead of individual research and education, all of which have caused in lack of necessary safeguard from management organization, operation mechanism to financial support.

\subsection{Inaccurate Positioning Target of Shaping Human Development}

Teachers in the general education of arts all have their own arts background but have not taken relevant curriculums of general education, which caused a lack of understanding to the spirit and purpose of general education of arts. Therefore, it is easy to stay in a shallow understanding stage that allows students only to broaden their horizons and cross-field learning. Lack of attention to the 
general education by teachers indirectly affect the cognition and learning attitude of students, as well as influence by university education concept of putting what is learned into practice, general art curriculum has become the main channel to ease pressure from major curriculums. Students generally think that general education is non-professional curriculums, and there is no need to take it seriously. The attitude of teachers and students to the general art curriculums influences each other in a vicious circle, which distorts the true spirit and purpose for general education of arts.

\subsection{Unsuitable Construction of Teachers' Team in General Education of Arts for Current Development in Higher Education}

There are two extreme tendencies of specialization and popularization in the teachers for general education of arts. On one hand, a large number of young teachers participate in general education, which integrate vigorous, new educational ways and methods into the classroom, and enhance activity in the classroom. However, behind the fancy mode, students gain no profound understanding when they recall the class. It is more of a new type of "input" transmission mode of teaching. On the other hand, a group of professional teachers, who are representatives of professional disciplines of pyramid, may take the classroom as a "console" for their expertise, where obscure professional language and obscure theory make the classroom "dead". These two extreme classroom models are inseparable from the teacher's own situation. Therefore, the construction of teachers' team, and reform of concept and models have become urgent problems to be solved.

Meanwhile, many teachers in colleges and universities are not willing to engage in teaching and research work for the general art curriculums. Therefore, the number of research results is small with uneven quality. Many of the current education is utilitarian in command. The evaluation standard for teachers' professional titles and awards are more discipline to their academic research results, which cause the teachers to focus on academic research, and ignore the characteristics of education and teaching, nor to fundamentally improve teaching quality and student quality. Hereby it has greatly affected the quality of teaching.

\subsection{Lack of Rational Planning and Connotation for the Curriculums of General Education of} Arts

Colleges and universities are lack of uniqueness for the accurate orientation of general education of arts. It has an unclear goal, and stays more at the popularization level. It shows feature of stereotype both from curriculum design and teaching methods, ignoring the differences of thinking mode, knowledge structure and cultural accomplishment among different majors.

Since all colleges and universities pay great attention to academic research, the curriculum planning for general education of arts is lack of continuity, systematic and holistic. Usually the schools themselves will set up the curriculum or simply do not set, while the curriculum set up is mainly based on the subjective intention of teachers randomly. The teachers often design the curriculum according to the students' preferences. With lack of innovation in teaching design, it shows futures of simple and interesting, which is only for common sense and appreciation, but no combination of artistic characteristics and school cultural characteristics. At the same time, as the evaluation standard is not high, it is easy for the students to pass so as to achieve the main purpose of increasing the number of students for optional curriculum, which makes the general education of arts more and more entertaining and one-sided, difficult to form a three-dimensional structure of discipline, and loses the proper meaning of curriculum of general education of arts. In addition, there are still problems of simple teaching model. The sense of participation of the student is not 
strong, as well as the lack of necessary and meaningful practice, make the students unable to really think and arouse ideological resonance in the curriculum.

\section{Countermeasures and Suggestions on the Main Problems in Current General Education of} Arts

The core of general education of arts is, after all, to build a sound personality through cultivating students' humanistic quality. General education of arts aims at cultivating aesthetic competence through human culture and caring for the world in which we live. Therefore, it is not only the cultivation of knowledge, but more of cultivation and education for a sound personality. It cultivates students' basic idea of meaning of life, evolution of civilization, social culture, changes of times and humanities and natural sciences, as well as cultivating their ability of clear thinking, objective judgment and fluent expression. In view of the aforesaid problems existing in the general education of arts, the author believes that it may be solved by adopting the following strategies:

\subsection{Pay Attention to the Important Position of the General Education of Arts and Exert Its Outstanding Role in Talent Training}

(1) Make clear the important role of general education of arts in shaping and perfecting personality of university students

In the National Long-term Education Reform and Development Plan (2010 - 2020) it pointed out that, "education is the fundamental way to improve the quality of people and promote the comprehensive development of people", and "to promote the comprehensive development of people and meet the needs of the society is the basic standard to measure the quality of education"; in order to promote the comprehensive development of students, it has to form a scientific and correct outlook on education and students, and a comprehensive and scientific evaluation on students; only in this way so it can guide and cultivate students correctly and comprehensively, and promote their healthy and all-round development. General education of arts plays an active and extensive role in carrying out the socialist core values and the construction of moral sentiments by carrying forward the truth, goodness and beauty. Therefore, the general education of arts shall take the cultivation of students' noble moral sentiments as the guide in terms of teaching objectives, training programs, curriculum setting, and teaching syllabus, etc., take the students as the foundation, and effectively promote the all-round development of students.

(2) Make Clear the Important Position of General Education of Arts in the Students' Knowledge Structure.

General education of arts is the core of aesthetic education, and it is an important curriculum of university general education. It can enhance students' creative consciousness, help them improve their aesthetic ability, and is a potential tool for university students to study and master other kinds of knowledge. For example, there is a strong complementarity between the general arts and science disciplines, as science is the soul of art, and art makes science more vivid. In colleges and universities, general education of arts is functioning as the most important foundation, which plays a key role in cultivating university students' thinking and innovation abilities.

(3) Make Clear General Education of Arts Is An Important Part of Modern Higher Education.

Pay attention to diversity and integrate teaching resources. Improve and strengthen the students' comprehensive ability by the wide range of Arts. Integrate cultural differences between China and western world to make traditional and modern blends, and construct a three-dimensional aesthetic framework. The design arrangement of each class, apart from teaching objective and content set due to the course name, shall pay attention to cultivation and guidance to the students. In the freshman's 
general art curriculum, main target of the curriculum shall be the introduction of basic knowledge of art, development of interest in art and critical thinking ability; for sophomore and junior students, the general art curriculum is mainly to explore different works of art form and style, broaden students' vision of art, help them to establish a good view of art, initiate their aesthetic experience through daily life stuff, and motivate their learning interest in art. In this way, it makes the students no longer have the sense of distance and strangeness in the art field, and makes the students to take the initiative to find art of life, and pursue the aestheticization of daily life. Especially in an era of great information, it is more necessary to cultivate students' keen insight and independent judgment in art.

\subsection{Complete the Mechanism and Organization of General Education of Arts, and Improve the Teaching and Educating Level.}

(1) Establish an exchange mechanism for general education of arts to enhance and enrich the teaching connotation of higher education.

At present, regular exchanges and cooperation mechanisms have not yet been formed between the curriculum of general education of arts and the relevant cross disciplines, and many deep-seated problems for the development of the disciplines have not been fully researched and explored; besides, exploration for the innovation model in general education of arts is still in the initial stage, and there is no benign interactive situation in which all kinds of innovative models are formed in true sense.

Teachers who are engaged in general education of arts have different educational backgrounds, teaching experiences and teaching concepts, which will affect their teaching methods and behavior. However, academics are more liberal in colleges and universities, teachers usually focus on research in their own field and there are lack of communication platform with other teachers. The teachers' teaching beliefs affect the design and curriculum content of the teaching, as well as the students' cognition and views on the content of education. Thereby, the author suggests that a teachers' seminar in the field of general education of arts be convened at the beginning of each semester to strengthen the understanding of teachers towards the purpose and spirit of general education of arts. It may also discuss problems encountered in teaching of general education of arts in meetings of the same field, share teaching experiences, deepen education and teaching philosophy, so as to enhance the teaching quality.

(2) Establish Standard Curriculum Quality and Evaluation Criteria, and Improve and Perfect the Teaching Evaluation System for General Education of Arts.

In Europe, America, Japan and other countries, general education of arts has formed a mature curriculum evaluation system standards, and has accumulated tremendous teaching experience. Colleges and universities in our country may learn from their experience appropriately, setting foot on the future trend of education development combined with their own actual situation, consolidate the existing teaching achievements from curriculum setup, construction of teachers' team and funding and other aspects, expand new way of education for general arts, renew the educational concepts, improve and perfect the general education of arts and form their own education characteristics. Set up the curriculum ability evaluation index, perfect the classroom teaching evaluation standard, set up the teaching team, unify the teaching outline and compile the teaching material. Each teacher may have a basis for curriculum design, but may also allow students to learn with cohesion and gradual progress. In term of curriculum evaluation design, reform in examination mode shall also be carried out with focus on assessment of the learning process, and make study run through the whole educating and teaching process. 
(3) Encourage Teachers to Innovate and Develop, and Improve the Teaching Level of General Education of Arts.

In view of current situation, related research in the field of general education of arts is still relatively scarce, and the key to successful implementation of general education lies in teachers of the course. Therefore, encouraging teachers to engage in research for general education of arts may, apart from obtaining more attention from the teachers, may also let them have a more in-depth understanding to the ideals and objectives in the field of general education of arts during the research, so as to improve their academic research ability, and strengthen the important role of arts in general education. In addition, the schools shall also set up an effective incentive mechanism, providing training and exchange platform, individual identify system of scientific research achievements, and create favorable conditions for teachers' career development.

\subsection{Enriching Realization Forms for General Education of Arts, and Improve Educating and Teaching Practice Effect}

(1) Establish A "Second Classroom" Curriculum Teaching Model, and Increase the Span of Teaching System for the General Education of Arts.

"Second class" is outside the school teaching plan, guiding and organizing students to carry out meaningful and healthy extracurricular activities. It plays an active role in dealing with the unity of students' generality and individuality, and enhancing students' creativity, flexibility and adaptability. It supports and coordinates with the "first class", and is an effective way and mean for cultivating talents and teaching in school. Exert the positive function of artistic community, make full use of all kinds of associations, community organizations, actively mobilize arts backbone and activists, and implement the "second classroom" by curriculum, combining the students' interest and way of learning together to make the learning content and learning mode scientific and professional, so that it not only can ensure the professional level of students, but also that teachers' class hours are guaranteed, and eventually the teaching design can be fully implemented.

(2) Establish A Multidisciplinary Collaboration and Scientific Development to Enhance the Teaching Effect of General Education of Arts.

Since the general education of arts involves many fields and disciplines, and learning background and knowledge of students are different, therefore, colleges and universities shall take the initiative to break the boundaries of disciplines, form a benign interaction mechanism with related disciplines and establish a new pattern of communication and cooperation. Explore a variety of teaching mode in the curriculum, and increase practical content such as organizing various cultural and artistic activities, investigating art venues and visiting a variety of art exhibitions and so on. Improve students' artistic level, and cultivate talents who meet social needs and with high artistic quality by multipronged approaches.

\subsection{Change Concept for General Education of Arts and Create A Good Environment for Art, Culture and Education.}

(1) Carry Out Differentiated Teaching for General Education of Arts and Professional Education of Arts.

Even evaluated by professional standards, the general education of arts is different from the professional education of arts. Students cannot be oriented by study of professional skills and techniques, but their aesthetic ability and level shall be improved in differ degree through learning and arts practice. It is not only simply to raise the technique level, but to cultivate and shape the students' aesthetic status, aesthetic realm, psychological status, degree of will, attitude towards life 
and other aspects. Through guiding students to explore different types of works of arts and ideas of expression, it helps them to construct their own artistic concepts from macro perspective, encourage them to pay more attention to arts information, initiatively browse websites and arts books, and actively participate in various arts activities. It helps students to gradually form a complete and mature system of aesthetic ideas through efforts of all aspects, and apply the aesthetic concept in daily life to become a lifelong beneficiary ability.

(2) Establish a good teaching environment for the general education of arts, improve college and university students' learning interest in arts courses.

Many teachers who are engaged in general education of arts sigh for the bad academic attitude of students, for example, late for class, dislike after-school homework, even put strict teachers in the blacklist for students' elective courses, which frequently causes embarrassment to teachers by failure to open a class due to insufficient enrollment. It has become a difficult problem for teachers to overcome that how to make the students have a positive attitude towards learning and pay attention to general education. Teaching is a complicated work, since people are independent individuals. Each person has a unique mode of thinking, which is innate or acquired. It is suggested that the schools shall promote the importance of general education of arts. Apart from educating students, teachers of the course are required to pay attention to the general education curriculum, and the students' cognitive biases towards general education shall be rectified, which can be achieved by creation of good atmosphere of arts through "elegant art enters into the campus”, folk custom exhibition, campus art festival and so on, of different levels and kinds of activities or competitions.

\section{Conclusion}

The problems existing in the general education of arts in colleges and universities have sounded the alarm for us and deserve the educators' reflection and immediate action. In the era of constant progress, talent competition has become increasingly fierce. In the face of competitions and challenges for the future, if it can broaden view and thinking of colleges and universities students in the teaching process of the general education of arts, improve their artistic accomplishment and aesthetic ability, and thus obtain more creative thinking, it will be of great advantage to enhance their comprehensive quality and innovation ability. Therefore, the future general education of arts shall focus on training students to establish a correct outlook on life and values, strengthen the cultivation of humanistic spirit, carry out the socialist core value in the practice of teaching, promote moral sentiment of truth, goodness and the beauty, cultivate students' sound personality, and show the important role of general education of arts in the University General Education Reform. Whether it is educational institutions or educators themselves, we shall pay high attention to the importance of general education of arts and its significance for people education, change the thinking philosophy, further improve and perfect the system and mechanism, gradually enrich the forms of realization, engage in creating excellent art, culture and education environment, raise the education level of general education of arts, and function as the communication link of social aesthetic. 


\section{References}

[1] Yuan, Ye. Art education and quality education in Universities. [J]. Tian Fu New Idea. 2005. 02

[2] Chen, Ping. The Current Situation and Future of General Education in Higher Art Education. [J]. Art Education. 2012.06

[3] Mei, Baoshu. Aesthetic Education and Quality Education Facing the New Century [D]. People's Publishing House. 2004.04.

[4] Yang, Lan. Research on Art Education in the Series of Quality Education in University. [J]. Art Education. 2006.07

[5] Guo, Shengjian. The Alienation of Art Education. [J]. Journal of Education Science of Hunan Normal University 2002

[6] Dong, Xuewen. Art Education is the Education of the Soul. [J]. China Music Education. 2000.04 